\title{
Kepemimpinan Transformasional Dalam Pembentukan Provinsi Kepulauan Mentawai
}

\author{
Wendy Sepmady Hutahaean \\ Institut Agama Kristen Negeri Tarutung \\ wendyhutahaean@gmail.com
}

\begin{abstract}
The research's purpose is to explain the importance of Transformational Christian Leadership by the Mentawai Islands Regency Government and the Central Government in the formation of Mentawai Islands Province. A qualitative descriptive approach is the method used in the research, that describes a symptom, event or incident that is currently the center of attention. Transformational Leadership Theory is a theory used in Christian Leadership, where a leader mingles among its members and always motivates its members to realize a common vision. Currently, Mentawai Islands Regency, located in West Sumatra Province, is a district occupied by the Mentawai tribe. The majority of the inhabitants of the Mentawai islands embrace Christianity, the only district that is majority Christian in West Sumatra, amounting to $77.6 \%$, of which $48.5 \%$ Protestants and 29.1\% Catholics. Meanwhile, the number of followers of Islam is 22.2\% and traditional beliefs are $0.2 \%$. There are five strategies in transforming the Mentawai Islands Regency into a Mentawai Islands Province, namely (1) Planning and Socialization of Regional Expansion, (2) Equalization of the Number of Villages in Each District, (3) Expansion of Districts and Villages of Coverage, (4) Establishing New Regencies and Cities, (5) Establishment and Consolidation of the Mentawai Islands Province.
\end{abstract}

Keywords: Leadership, Transformational, Province, Island, Mentawai

\begin{abstract}
Abstrak: Penelitian ini bertujuan untuk menjelaskan pentingnya suatu Kepemimpinan Transformasional oleh Pemerintah Kabupaten Kepulauan Mentawai hingga Pemerintah Pusat dalam pembentukan Provinsi Kepulauan Mentawai. Pendekatan Kualitatif Deskriptif merupakan metode yang digunakan dalam penelitian ini, yaitu menjelaskan suatu gejala, peristiwa atau kejadian yang sedang menjadi pusat perhatian saat ini. Teori Kepemimpinan Transformasional adalah teori yang digunakan dalam Kepemimpinan Kristen, yaitu pemimpin yang membaur dan selalu memotivasi anggotanya untuk mewujudkan visi bersama. Saat ini, Kabupaten Kepulauan Mentawai termasuk ke dalam Provinsi Sumatera Barat adalah sebuah kabupaten yang ditempati oleh suku Mentawai. Sebagian besar penduduk kepulauan Mentawai adalah agama Kristen, satu-satunya kabupaten yang mayoritas Kristen di Sumatera Barat, berjumlah 77,6\%, dimana Protestan 48,5\% dan Katolik 29,1\%. Sedangkan pemeluk agama Islam sebanyak 22,2\% dan kepercayaan tradisional $0,2 \%$. Terdapat lima strategi dalam mentransformasi Kabupaten Kepulauan Mentawai menjadi sebuah Provinsi Kepulauan Mentawai, yaitu (1) Perencanaan dan Sosialisasi Pemekaran Daerah, (2) Pemerataan Jumlah Desa Setiap Kecamatan, (3) Pemekaran Kecamatan dan Desa Cakupannya, (4) Pembentukan Kabupaten dan Kota Baru, dan (5) Pemantapan Pembentukan Provinsi Kepulauan Mentawai.
\end{abstract}

Kata Kunci: Kepemimpinan, Transformasional, Provinsi, Kepulauan, Mentawai

\begin{tabular}{llll}
\hline Article History : & Received: 11-05-2021 & Revised: 29-06-2021 Accepted: 29-06-2021 \\
\hline
\end{tabular}




\section{Pendahuluan}

UUD RI 1945 menjabarkan wilayah RI dibagi atas beberapa daerah provinsi dan daerah provinsi dibagi atas beberapa kabupaten dan kota yang memiliki pemerintahan masing-masing untuk menjalankan otonomi daerah yang seluas-luasnya. ${ }^{1}$ Otonomi daerah merupakan wewenang, hak, dan kewajiban daerah untuk mengelola dan mengurus urusan pemerintahan sendiri dan kepentingan rakyat masing-masing. ${ }^{2}$ Kesempatan untuk pembentukan daerah otonomi baru (DOB) masih terus dibahas dan dikaji pada level daerah maupun level pusat. Dalam sejarah pemerintahan di Indonesia, pemekaran wilayah atau pembentukan DOB sebenarnya bukanlah hal yang baru. Pemerintah telah banyak melakukan pemekaran wilayah. Pada masa Orde Lama dilakukan pemecahan provinsi-provinsi di luar Pulau Jawa yang dilatarbelakangi oleh wilayah yang terlampau luas. Pada masa Orde Baru, apabila suatu kecamatan semakin menguat karakter urbannya, maka kecamatan tersebut akan berubah status menjadi Kota Administratif. Selanjutnya seiring berjalannya pembangunan dan pola hidup perkotaan di wilayah tersebut semakin tinggi, daerah tersebut dapat meningkat menjadi Kotamadya atau Kota yang setingkat dengan Pemerintahan Kabupaten. ${ }^{3}$ Pada masa pasca 1999 terjadi ledakan penambahan DOB yang terdiri dari kabupaten, kota, dan provinsi baru. ${ }^{4}$

Secara administrative, Kabupaten Kepulauan Mentawai terletak di Provinsi Sumatera Barat berdasarkan UU No. 49 Tahun 1999 dan dikelilingi oleh Samudaera Hindia. Terdapat 4 pulau besar yakni Siberut, Sipora, Pagai Utara dan Pagai Selatan dan ditempati oleh suku Mentawai. Selain itu ada beberapa pulau kecil lainnya yang sebagian besar dimanfaatkan sebagai tempat perladangan. Daerah ini memiliki potensi alam yang banyak yaitu dalam bidang perkebunan, pertanian, dan perikanan. Hasil laut merupakan salah satu potensi yang terus dikembangkan di kabupaten ini terutama ikan kerapu yang laku untuk diekspor. Selain itu ada sektor wisata yang didukung oleh pantai-pantai yang cocok dijadikan resor dan ombak tinggi yang sesuai untuk berselancar. Untuk menyokong pembangunan di daerah ini pemerintah pusat dan daerah merencanakan akan membangun PLTU Tuapejat.

Dilihat dari aspek sosiokultural, Kepulauan Mentawai berbeda dengan wilayah lainnya di Provinsi Sumatera Barat. Penduduknya didominasi oleh masyarakat suku Mentawai yang adat budayanya berbeda dengan masyarakat suku Minangkabau. Masyarakat Mentawai masih memegang nilai-nilai dari kepercayaan Arat Sabulungan

\footnotetext{
${ }^{1}$ Republik Indonesia, Undang-Undang Dasar Negara Republik Indonesia (Jakarta, 2002).

2 Republik Indonesia, Undang-Undang Republik Indonesia Nomor 32 Tahun 2004 Tentang Pemerintahan Daerah (Jakarta, 2004).

3 Herry Wiryono, “Cilegon: Dari Kota Administratif Sampai Kota (1986-2005)," Patanjala 1, no. 3 (2009): 296-306.

${ }^{4}$ Andik Wahyun Muqoyyidin, "Pemekaran Wilayah Dan Otonomi Daerah Pasca Reformasi Di Indonesia: Konsep, Fakta Empiris, Dan Rekomendasi Ke Depan,” Jurnal Konstitusi 10, no. 2 (2013): 287309.
} 
yang memandang roh/arwah memiliki derajat yang sama dengan manusia, digambarkan pada interaksi Sikerei (tokoh sentral adat yang berperan dalam pengobatan) dengan roh untuk mengambil keputusan dan interaksi dengan tumbuhan yang akan dijadikan obat. ${ }^{5}$ Sementara masyarakat Minangkabau sudah sepenuhnya memegang nilai-nilai keislaman yang terintegrasi dengan adat budaya dengan prinsip adat bersandikan syariat Islam, syariat bersandikan Quran. ${ }^{6}$ Dalam aspek sosioekonomi, masyarakat Mentawai dalam berbagai kesempatan mengkonsumsi babi sebagai sumber protein, seperti pada saat acara-acara adat. ${ }^{7}$ Setiap rumah (uma) biasanya memiliki kandang babi di bawah kolongnya dan babi merpakan hewan ternak yang sentral dalam budaya Mentawai, ${ }^{8}$ seperti hewan kerbau dalam budaya Toraja. Penduduk di Kabupaten Kepulauan Mentawai didominasi oleh pemeluk agama Kristen Protestan (48,5\%) dan Katolik $(29,1 \%)$ yang apabila digabungkan mencapai $77,6 \%$ sementara pemeluk Islam 22,2\%.

Dari segi geografi, potensi daerah, dan aspek sosiokultural, Kepulauan Mentawai memiliki potensi untuk menjalankan otonominya sendiri. Berkaca dari Kepulauan Nias yang berlatar belakang sosial budaya berbeda dari daratan utama Sumatera Utara, mereka kini mengajukan pemekaran menjadi provinsi baru. ${ }^{9}$ Dalam hal ekonomi, Kepulauan Mentawai termasuk ke dalam kriteria daerah tertinggal, ${ }^{10}$ sehingga perlu pembangunan yang lebih ditingkatkan.

Dalam merealisasikan pengajuan DOB ini dan mempersiapkan segala syarat yang mendukung pemekaran, dibutuhkan kepemimpinan dari pemerintah daerah maupun pusat, terutama para putra daerah. Kepemimpinan Kristen dapat dijadikan acuan dalam hal ini melihat latar belakang masyarakat Mentawai yang sebagian besar menganut agama Kristen dan pemimpin daerahnya juga berkeyakinan dan dari partai bercirikan Kristen. Kepemimpinan transformasional/transformatif merupakan model kepemimpinan yang dimiliki Yesus Kristus dan dapat membawa perubahan ke arah kemajuan. ${ }^{11}$

${ }^{5}$ Apri Damai Sagita Krissandi, Sebastianus Widanarto, and Wilma Endah Utami, "Posthumanisme Masyarakat Mentawai," Prosiding Seminar Nasional Indonesia di Tengah Tantangan Pascahumanisme: Merumuskan Model Humanisme Baru (2019): 9-15.

${ }^{6}$ Aulia Rahmat, "Reaktualisasi Nilai Islam Dalam Budaya Minangkabau Melalui Kebijakan Desentralisasi," El-HARAKAH: Jurnal Budaya Islam 13, no. 1 (2011).

${ }^{7}$ Syaiful Kasman, "BABI : TERNAK KESAYANGAN ORANG MENTAWAI," Jurnal Antropologi: Isu-Isu Sosial Budaya 17, no. 1 (2015): 87-95.

${ }^{8}$ Krismanto Kusbiantoro, Roy Anthonius, and Iwan Santosa, "Modernisasi Dan Komersialisasi Uma Masyarakat Mentawai Sebuah Deskripsi Fenomenologis," Jurnal Sosioteknologi 15, no. 2 (2016): 187199.

${ }^{9}$ Ben Hansel N. Zebua and M. Y. Tiyas Tinov, "Upaya Pemekaran Provinsi Kepulauan Nias (Studi Kepentingan Elit Politik)," Jurnal Online Mahasiswa Fakultas Ilmu Sosial dan Ilmu Politik 4, no. 1 (2017).

10 Presiden Republik Indonesia, Lampiran Peraturan Presiden Republik Indonesia No. 63 Tahun 2020 Tentang Penetapan Daerah Tertinggal Tahun 2020-2024 (Jakarta, 2020).

${ }^{11}$ Harun Y. Natonis, "Kepemimpinan Transformatif Dalam Perspektif Pendidikan Agama Kristen," Voice of Wesley: Jurnal Ilmiah Musik dan Agama 3, no. 2 (2020): 15-27. 
Dari latar belakang wacana pemekaran Kabupaten Kepulauan Mentawai tersebut, dirumuskan beberapa masalah dalam penelitian ini. Pertama, apa faktor yang mempengaruhi pemekaran Kepulauan Mentawai menjadi provinsi? Kedua, apa saja wilayah yang dapat ditransformasi dalam pemekaran wilayah tersebut? Ketiga, kepemimpinan Kristen yang transformasional seperti apa yang dapat mentransformasi dan mewujudkan wacana pemekaran Kepulauan Mentawai?

\section{Metode Penelitian}

Pendekatan Kualitatif Deskriptif merupakan metode yang digunakan dalam penelitian ini, yaitu menjelaskan suatu gejala, peristiwa atau kejadian yang sedang menjadi pusat perhatian saat ini. Teknik pengumpulan data dilakukan dengan metode studi pustaka yang sumbernya dari data sekunder yaitu artikel jurnal, dokumen kebijakan pemerintah/perundang-undangan, buku, dan sumber pustaka lainnya. Pustaka didapat dengan menggunakan buku, google book, jurnal, dan berbagai berita.

\section{Hasil dan Pembahasan}

\section{Proses Pengusulan Pemekaran Wilayah}

Dalam Peraturan Pemerintah Nomor 78 Tahun 2007 (PP No. 78/07), ada 3 persyaratan yang mendasari proses pembentukan daerah, yaitu administratif, teknis, dan fisik kewilayahan. ${ }^{2}$ Persyaratan ini dimaksudkan agar DOB mampu menyelenggarakan otonomi daerah dalam rangka peningkatan pelayanan publik yang optimal sehingga mempercepat terwujudnya kesejahteraan masyarakat dan pada akhirnya dapat memperkokoh keutuhan NKRI.

a. Syarat administratif didasarkan pada suara atau aspirasi sebagian besar masyarakat.

b. Syarat teknis didasarkan pada potensi daerah, faktor ekonomi, sosial budaya, sosial politik, kependudukan, pertahanan, keamanan, luas daerah, dan faktor lain yang mendukung berjalannya otonomi daerah meliputi rentang kendali penyelenggaraan pemerintahan, pertimbangan kemampuan keuangan, dan tingkat kesejahteraan masyarakat.

c. Syarat fisik kewilayahan meliputi sarana dan prasarana pemerintahan, cakupan wilayah, dan lokasi calon ibukota.

Pembentukan suatu daerah harus dilengkapi dengan kajian oleh tim yang dibentuk kepala daerah yang bersangkutan untuk menilai kelayakan pembentukan DOB secara objektif mencakup penilaian kuantitatif terhadap faktor-faktor teknis dan memastikan daerah induk tetap mampu menyelenggarakan otonomi daerahnya. ${ }^{13}$ Penilaian kuantitatif ini dilengkapi dengan proyeksi 10 (sepuluh) tahun ke depan dari faktor-faktor dominan (kemampuan ekonomi, kemampuan keuangan, potensi daerah, kependudukan)

12 Presiden Republik Indonesia, Penjelasan Atas Peraturan Pemerintah Republik Indonesia No. 78 Tahun 2007 Tentang Cara Pembentukan, Penghapusan, Dan Penggabungan Daerah (Jakarta, 2007).

13 Ibid. 
dan Rencana Tata Ruang Wilayah Daerah Induk disertai penilaian kualitatif terhadap faktor-faktor lain yang memiliki karakteristik tersendiri seperti kondisi etnik, potensi konflik dan historis, serta potensi sumber daya alam yang belum tergali. Aturan yang mengatur tata cara pembentukan daerah sangat menitikberatkan pada dukungan dan inisiatif daerah pada proses inisiasi pembentukan daerah. ${ }^{14} \mathrm{Hal}$ ini terlihat jelas pada alur proses pengusulan pemekaran daerah sesuai dengan Pasal 14 sampai 21 PP No. 78 Tahun 2007.

Dari berbagai wacana publik dan kajian akademis dapat dilihat bahwa dorongan pemekaran selama ini lebih banyak berasal dari tuntutan daerah. ${ }^{15}$ Alasan utama yang melatarbelakangi daerah mengajukan pemekaran diantaranya:

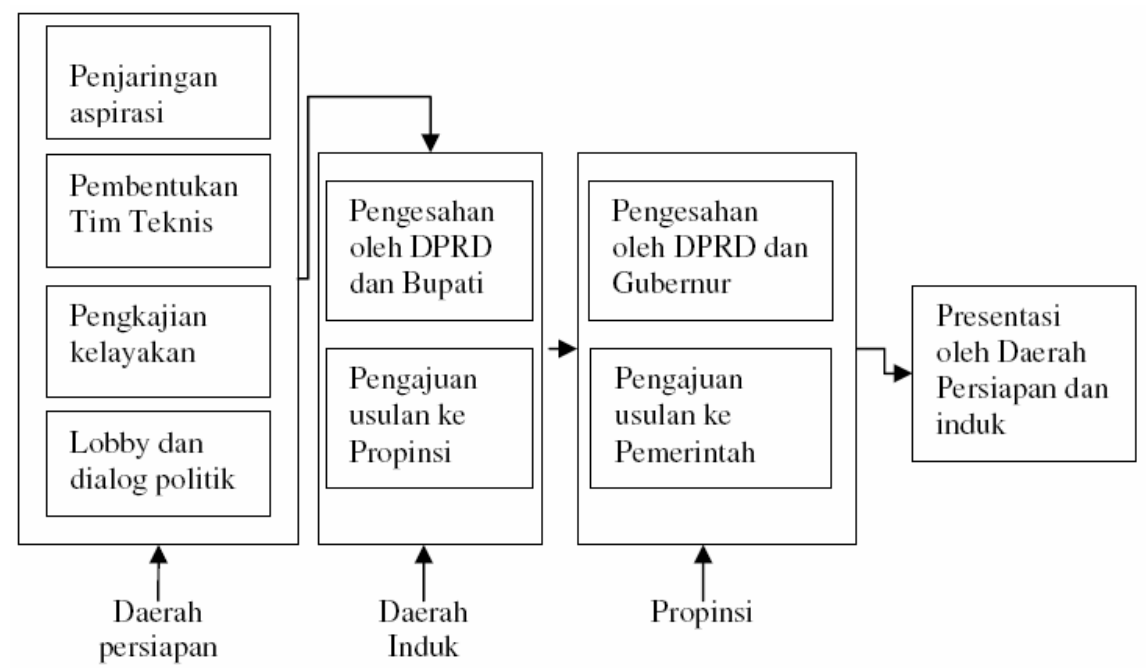

\section{Gambar 1. Proses Pengusulan Pemekaran Daerah di Tingkat Pemerintah Daerah}

a) Kebutuhan akan pemerataan ekonomi daerah. Ini adalah alasan yang paling populer digunakan untuk pemekaran daerah menurut data IRDA.

b) Terlalu luasnya kondisi geografis. Pada banyak kasus di Indonesia, pengelolaan pemerintahan dan pelayanan publik kurang terlaksana dengan optimal dan kurang efektif untuk daerah yang wilayahnya terlalu luas karena infrastruktur yang tidak memadai.

c) Perbedaan basis identitas (etnis, asal muasal keturunan). Pengajuan pemekaran dapat dilatarbelakangi oleh masyarakat yang berdomisili di daerah pemekaran merasa sebagai komunitas budaya tersendiri yang berbeda dengan daerah induk.

d) Pengelolaan konflik komunal yang selalu gagal. Kekacauan politik yang menemui jalan buntu sering menimbulkan adanya tuntutan pemisahan daerah.

\footnotetext{
14 Ibid.

15 Ibid.
} 
e) Adanya insentif fiskal melalui Dana Alokasi Umum (DAU) dan Dana Alokasi Khusus (DAK), bagi hasil Sumber Daya Alam, dan Pendapatan Asli Daerah bagi daerah baru hasil pemekaran yang dijamin oleh Undang-Undang.

Pada tingkat pusat, prosedur pembahasan untuk meloloskan usulan proposal pembentukan DOB secara teknokratis digambarkan sebagaimana diagram alir berikut ini.

\section{Persyaratan Administratif}

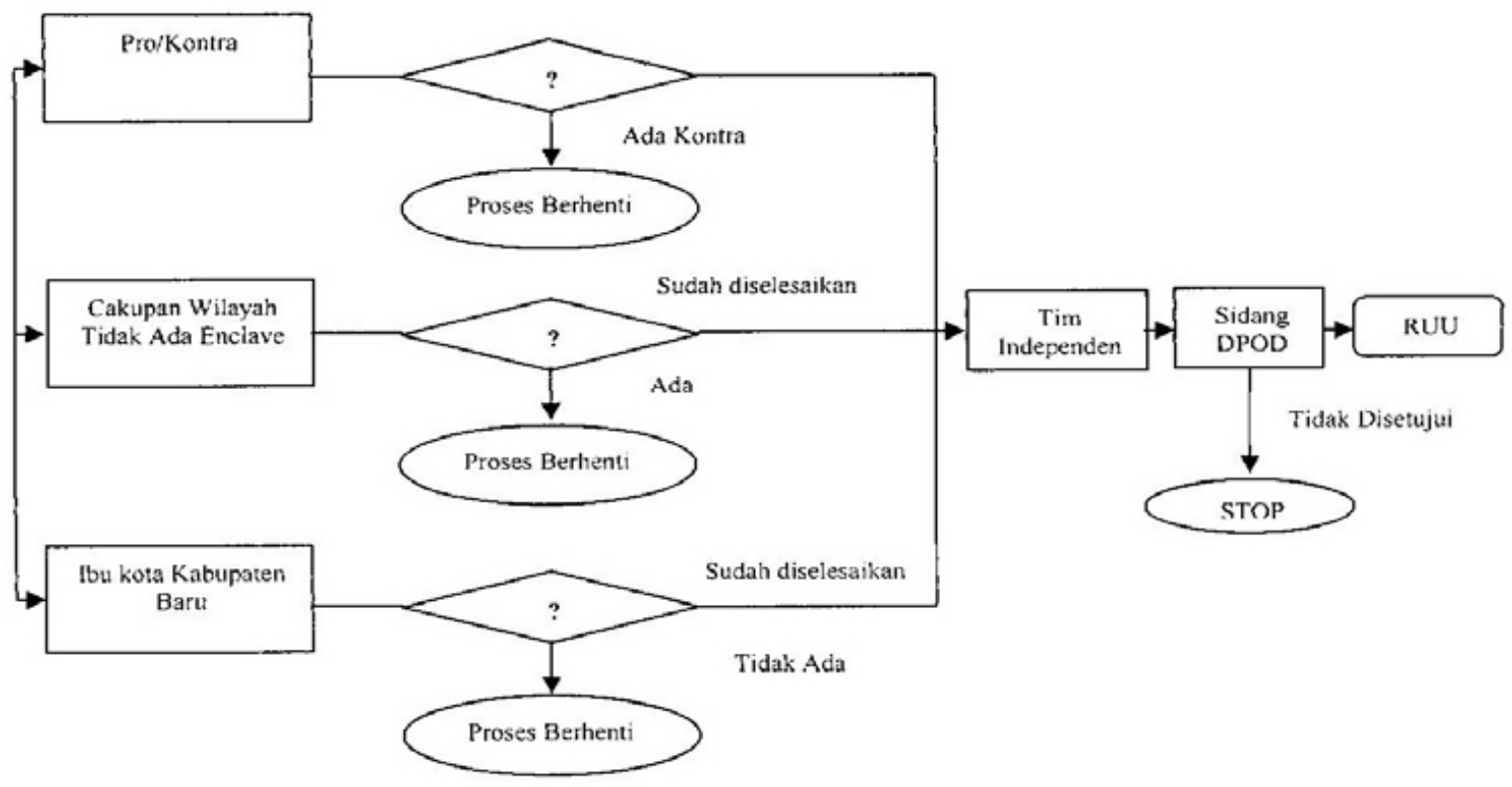

Gambar 2. Proses Pengusulan Pemekaran Daerah di Tingkat Pemerintah Pusat

Saat ini memang belum ada masyarakat Mentawai baik dari Kabupaten Kepulauan Mentawai maupun dari luar kabupaten yang menyampaikan aspirasi untuk pemekaran Kepulauan Mentawai menjadi sebuah provinsi. Namun, pemekaran Mentawai dari Kabupaten Padang Pariaman adalah aspirasi ${ }^{16}$ dan dimotori organisasi masyarakat Mentawai. ${ }^{17}$ Kepemimpinan dari pemerintah daerah dan tokoh masyarakat Mentawai sangat diperlukan dalam menggerakkan berbagai stakeholder mulai dari visi untuk kemandirian Mentawai sebagai provinsi, penataan wilayah dan ekonomi desa dan kecamatan, ${ }^{18}$ hingga wacana pembentukan desa dan kecamatan baru sehingga masyarakat nantinya siap untuk wacana provinsi baru. ${ }^{19}$

${ }^{16}$ Republik Indonesia, Undang-Undang Republik Indonesia No. 49 Tahun 1999 Tentang Pembentukan Kabupaten Kepulauan Mentawai (Jakarta, 1999).

${ }^{17}$ Kominfo Mentawai, "Yudas: Sepintas Dalam Sejarah Terkait Mekarnya Mentawai Menjadi Kabupaten," last modified 2019, accessed June 17, 2021, http://www.mentawaikab.go.id/berita/detail/yudas--sepintas-dalam-sejarah-terkait-mekarnyamentawai-menjadi-kabupaten-.

18 Kemenko PMK, "Pemerintah Matangkan Rencana Penataan Desa Di Kabupaten Kepulauan Mentawai," last modified 2021, accessed June 29, 2021, https://www.kemenkopmk.go.id/pemerintahmatangkan-rencana-penataan-desa-di-kabupaten-kepulauan-mentawai.

19 Joni Abdul Kasir, “Pemerataan Pembangunan, Mentawai Ajukan Pemekaran 40 Desa Baru," last modified 2019, accessed June 17, 2021, https://klikpositif.com/baca/48396/pemerataan-pembangunanmentawai-ajukan-pemekaran-40-desa-baru.html. 


\section{Persyaratan Teknis}

Secara sosio-ekonomi Mentawai masih jauh dari kriteria pemekaran sebagai provinsi. ${ }^{20}$ Dari sisi sosial budaya, Kepulauan Mentawai yang mayoritas suku Mentawai memiliki latar belakang budaya yang berbeda dari kabupaten lainnya di Sumatera Barat yang Minangkabau. Wacana kebijakan dari pemerintah provinsi terkadang kontraproduktif terhadap kepentingan suku Mentawai, misalnya wacana status Sumatera Barat sebagai Daerah Istimewa Minangkabau. ${ }^{21}$ Budaya Mentawai yang masih kuat memegang nilai-nilai Arat Sabulungan bertentangan dengan nilai keislaman suku Minangkabau, berbeda dengan agama Kristen yang dapat mengakomodasi kultur Mentawai seperti di uma biasanya harus ada ternak babi. Hal ini juga yang membuat pemeluk agama di Mentawai didominasi oleh Kristen (77,6\%), baik itu Protestan (48,5\%) maupun Katolik (29,1\%), sedangkan umat Islam sebesar 22,2\% dan sisanya memeluk kepercayaan 0,2\%. ${ }^{22}$ Populasi Kabupaten Kepulauan Mentawai pada tahun 2020 sebanyak 87.623 jiwa dengan luas wilayah 6.033,76 km². Dari jumlah penduduk memang masih jauh dari layak dimekarkan, namun dari luas wilayah sudah dapat dimekarkan. Sebagai perbandingan provinsi Kalimantan Utara yang paling sedikit penduduknya ada 708,4 ribu jiwa ${ }^{23}$ dan Kepulauan Nias yang profil wilayahnya mirip memiliki luas 5.625 $\mathrm{km}^{2}{ }^{24}$

Dari aspek sosio-politik, Mentawai memiliki putra-putra daerah yang duduk di dalam pemerintahan dan juga organisasi Forum Komunikasi Masyarakat Mentawai (FKMM) dan Ikatan Pemuda Pelajar Mentawai (IPMEN). Di sisi pertahanan dan keamanan, Mentawai merupakan wilayah pulau-pulau terluar yang berbatasan dengan Samudra Hindia dan merupakan wilayah rawan bencana. Rentang kendali ibukota akan semakin dekat bila Mentawai menjadi provinsi melihat wilayah geografis berupa kepulauan dengan akses transportasi menuju ibukota 3 kali seminggu melalui kapal feri.

\footnotetext{
${ }^{20}$ Joan Marta, "Faktor Pemicu Dan Penentu Kelayakan Pemekaran Wilayah Di Sumatera Barat (Pendekatan Sosial Ekonomi)," Jurnal Ecosains 1, no. 1 (2012): 67-76.

${ }^{21}$ Rus Akbar Saleleubaja, "Usulan Sumbar Menjadi DIM, Ini Kata Sejumlah Tokoh Dari Mentawai," last modified 2021, accessed June 17, 2021, https://www.mentawaikita.com/baca/5216/usulan-sumbarmenjadi-dim-ini-kata-sejumlah-tokoh-dari-mentawai.

22 BPS Kabupaten Kepulauan Mentawai, "Jumlah Penduduk Menurut Agama Dan Kecamatan (Jiwa), 2019-2020," last modified 2020, accessed June 17, 2021, https://mentawaikab.bps.go.id/indicator/108/560/1/jumlah-penduduk-menurut-agama-dankecamatan.html.

23 BPS Republik Indonesia, "Jumlah Penduduk Hasil Proyeksi Menurut Provinsi Dan Jenis Kelamin (Ribu Jiwa), 2018-2020,” last modified 2020, accessed June 17, 2021, https://www.bps.go.id/indicator/12/1886/1/jumlah-penduduk-hasil-proyeksi-menurut-provinsi-danjenis-kelamin.html.

24 BPS Provinsi Sumatera Utara, "Luas Daerah Dan Jumlah Pulau Menurut Kabupaten/Kota Di Provinsi Sumatera Utara, 2020," last modified 2020, accessed June 17, 2021, https://sumut.bps.go.id/statictable/2021/04/19/2066/luas-daerah-dan-jumlah-pulau-menurutkabupaten-kota-di-provinsi-sumatera-utara-2020.html.
} 
Tingkat kesejahteraan masyarakat Mentawai masih rendah dan digolongkan sebagai wilayah 3T (tertinggal, terluar, dan terdepan).

\section{Perencanaan dan Sosialisasi Pemekaran Daerah (Persyaratan Fisik Wilayah)}

Pemerintah daerah perlu membuat suatu perencanaan yang matang serta sosialisasi rencana pemekaran tersebut, baik dengan pemerintah pusat, masyarakat dan pihak-pihak yang berkepentingan. Kabupaten Kepulauan Mentawai pada tahun 2018 secara administratif memiliki 10 kecamatan, 43 desa dan 341 dusun. ${ }^{25}$ Kesepuluh kecamatan tersebut adalah sebagai berikut:

a) Kecamatan Pagai Selatan, luas daerah 901,08 $\mathrm{km}^{2}$ (14,99 \%) dan ibu kota kecamatan di Bulasat. Kecamatan Pagai Selatan terbagi ke dalam 4 desa, antara lain Bulasat, Makalo, Malakopak, dan Sinaka.

b) Kecamatan Sikakap, luas daerah $278,45 \mathrm{~km}^{2}$ (4,63 \%) dan ibu kota kecamatan di Sikakap. Kecamatan Sikakap terbagi ke dalam 3 desa, antara lain Matobek, Sikakap, dan Taikako.

c) Kecamatan Pagai Utara, luas daerah 342,02 $\mathrm{km}^{2}$ (5,69 \%) dan ibu kota kecamatan di Saumanganyak. Kecamatan Pagai Utara terbagi ke dalam 3 desa, antara lain: Betumonga, Saumanganyak, dan Silabu.

d) Kecamatan Sipora Selatan, luas wilayah 268,47 km² (4,47 \%) dan ibu kota kecamatan di Sioban. Kecamatan Sipora Selatan terbagi ke dalam 7 desa, antara lain Beriulou, Bosua, Mara, Matobe, Nem-Nem Leleu, Saureinu, dan Sioban.

e) Kecamatan Sipora Utara, luas wilayah 383,08 $\mathrm{km}^{2}$ (6,37 \%) dan ibu kota kecamatan di Sido Makmur. Kecamatan Sipora Utara terbagi ke dalam 5 desa dan 1 kelurahan, antara lain Betumonga, Bukit Pamewa, Goissoinan, Sido Makmur, Sipora Jaya, dan Tuapejat (ibu kota Kabupaten Kepulauan Mentawai).

f) Kecamatan Siberut Selatan, luas wilayah 508,33 $\mathrm{km}^{2}$ (8,46\%) dan ibu kota kecamatan di Maileppet. Kecamatan Siberut Selatan terbagi ke dalam 5 desa, antara lain Madobak Ugai, Maileppet, Matotonan, Muara Siberut, dan Muntei.

g) Kecamatan Siberut Barat Daya, luas wilayah 649,08 $\mathrm{km}^{2}$ (10,80 \%) dan ibu kota kecamatan di Pasakiat Taileleu. Kecamatan Siberut Barat Daya terbagi ke dalam 3 desa, antara lain Katurai, Pasakiat Teileleu, dan Sagalubbek.

h) Kecamatan Siberut Tengah, luas wilayah 739,87 $\mathrm{km}^{2}$ (12,31 \%) dan ibu kota kecamatan di Saibi Samukop. Kecamatan Siberut Tengah terbagi ke dalam 3 desa, antara lain Cimpungan, Saibi Samukop, dan Saliguma.

i) Kecamatan Siberut Utara, luas wilayah $816,11 \mathrm{~km}^{2}$ (13,58 \%) dan ibu kota kecamatan di Muara Sikabaluan. Kecamatan Siberut Utara terbagi ke dalam 6 desa, antara lain Bojakan, Malancan, Mongan Poula, Muara Sikabaluan, Sirilogui, dan Sotboyak.

${ }^{25}$ BPS Kabupaten Kepulauan Mentawai, “Banyaknya Desa Dan Dusun Di Kecamatan 2017-2018," last modified 2018, accessed June 30, 2021, https://mentawaikab.bps.go.id/indicator/101/100/1/banyaknya-desadan-dusun-di-kecamatan.html. 
j) Kecamatan Siberut Barat, luas wilayah 1.124,86 $\mathrm{km}^{2}$ (18,71 \%) dan ibu kota kecamatan di Simalegi (Betaet). Kecamatan Siberut Barat terbagi ke dalam 3 desa, yaitu Sigapokna, Simalegi, dan Simatalu Sipokak.

\section{Pemerataan Jumlah Desa Setiap Kecamatan}

Jika diperhatikan, jumlah desa untuk membentuk suatu kecamatan di Kabupaten Kepulauan Mentawai adalah minimal 3 desa. Pemerintah dapat memekarkan kecamatankecamatan yang terdiri dari lebih 3 desa, yaitu:

a) Pemekaran Kecamatan Sipora Utara. Kecamatan Sipora Utara yang terdiri dari 6 desa dapat dimekarkan menjadi 2 kecamatan. Pertama, pemekaran Kecamatan Sipora Barat yang terdiri dari 3 desa, yaitu Betumonga, Bukit Pamewa, dan Gosooinan. Kedua, induk Kecamatan Sipora Utara yang terdiri dari 3 desa, yaitu Sido Makmur, Sipora Jaya, dan Tuapejat.

b) Pemekaran Kecamatan Sipora Selatan. Kecamatan Sipora Selatan yang terdiri dari 7 desa dapat dimekarkan menjadi 2 kecamatan. Pertama, pemekaran Kecamatan Sipora Tenggara yang terdiri dari 3 desa, yaitu Nemnem Leleu, Bosua, dan Beriulou. Kedua, induk Kecamatan Sipora Selatan yang terdiri dari 4 desa, yaitu Saureinu, Matobe, Mara, dan Sioban.

c) Pemekaran Kecamatan Siberut Utara Kecamatan Sipora Utara yang terdiri dari 6 desa dapat dimekarkan menjadi 2 kecamatan. Pertama, pemekaran Kecamatan Siberut Timur yang terdiri dari 3 desa, yaitu Sirilogui, Sotboyak, dan Bojakan. Kedua, induk Kecamatan Siberut Utara yang terdiri dari 3 desa, yaitu Mongan Poula, Malancan, dan Muara Sikabaluan.

\section{Pemekaran Kecamatan dan Desa Cakupannya}

Walaupun pemerintah sudah melakukan pemekaran kecamatan, namun masih terdapat beberapa kecamatan yang cakupannya terdiri lebih dari 3 desa. Namun demikian, jika kecamatan tersebut dimekarkan menjadi 2 kecamatan, jumlah desa cakupan di kecamatan yang dimekarkan akan berjumlah kurang dari 3 desa. Untuk mengatasi masalah ini, maka pemerintah daerah dapat terlebih dahulu membentuk desadesa baru untuk memenuhi persyaratan pemekaran sebuah kecamatan menjadi minimal 3 desa setiap kecamatannya.

a) Pengembangan Desa di Kecamatan Pagai Selatan sehingga dapat dipecah menjadi 2 kecamatan. Pertama, pemekaran Kecamatan Pagai Tenggara sehingga terdiri dari 3 desa, yaitu Makalo, Malakopak, dan 1 desa baru. Kedua, induk Kecamatan Pagai Selatan dimekarkan sehingga terdiri dari 3 desa, yaitu Bulasat, Sinaka, dan 1 desa baru.

b) Pengembangan Desa di Kecamatan Siberut Selatan sehingga dapat dipecah menjadi 2 kecamatan. Pertama, pemekaran Kecamatan Siberut Tenggara sehingga terdiri dari 
3 desa, yaitu Muntei, Muara Siberut, dan 1 desa baru. Kedua induk Kecamatan Siberut Selatan terdiri dari 3 desa, yaitu Maileppet, Madobak Ugai, dan Matotonan

c) Pengembangan Desa di Kecamatan Sipora Selatan sehingga dapat dipecah menjadi 2 kecamatan. Pertama, Pemekaran Kecamatan Sipora Timur sehingga terdiri dari 3 desa, yaitu Saureinu, Matobe, dan 1 desa baru. Kedua, induk Kecamatan Sipora Selatan dimekarkan sehingga terdiri dari 3 desa, yaitu Mara, Sioban, dan 1 desa baru.

\section{Pembentukan Kabupaten dan Kota Baru}

Pemerintah Daerah dapat membentuk kabupaten baru yang terdiri dari minimal 3 kecamatan dan pemekarannya. Sedangkan pembentukan kota terdiri dari minimal 2 kecamatan, seperti berikut. Hal ini dikarenakan Kabupaten Kepulauan Mentawai merupakan daerah terluar Republik Indonesia dan termasuk ke dalam derah tertinggal yang perlu untuk segera bertransformasi menjadi sebuah provinsi baru.

a) Pembentukan Kota Tuapejat. Kota ini akan beribukota di Tuapejat yang terdiri dari 2 kecamatan, yaitu Kecamatan Sipora Utara (ibukota di Sido Makmur) dan Pemekaran Kecamatan Sipora Barat (ibukota di Betumonga).

b) Pembentukan Kabupaten Sipora. Kabupaten ini akan beribukota di Sioban yang terdiri dari 4 kecamatan, yaitu Kecamatan Sipora Selatan (ibukota di Sioban), Pemekaran Kabupaten Sipora Tenggara (ibukota di Bosua) dan Pemekaran Kabupaten Sipora Timur (ibukota di Matobe).

c) Pembentukan Kabupaten Pagai. Kabupaten ini akan beribukota di Sikakap terdiri dari 4 kecamatan, yaitu Kecamatan Pagai Selatan (ibukota di Bulasat), Kecamatan Pagai Utara (ibukota di Saumanganyak), Kecamatan Sikakap (ibukota di Sikakap), dan Pemekaran Kecamatan Pagai Tenggara (ibukota di Makalo).

d) Pembentukan Kabupaten Siberut. Kabupaten ini akan beribukota di Cimpungan terdiri dari 4 kecamatan, yaitu Kecamatan Siberut Utara (ibukota di Muara Sikabaluan), Kecamatan Siberut Barat (ibukota di Simalegi), Kecamatan Siberut Tengah (ibukota di Saibi Samukop), dan Pemekaran Kabupaten Siberut Timur (ibukota di Sirilogui)

e) Induk Kabupaten Kepulauan Mentawai yang tadinya beribukota di Tuapejat (telah dimekarkan menjadi Kota Tuapejat) akan berpindah ibukota di Madobak dan terdiri dari 3 kecamatan, yaitu Kecamatan Siberut Barat Daya (ibukota di Pasakiat Taileleu), Kecamatan Siberut Selatan (ibukota di Maileppet), dan Pemekaran Kabupaten Siberut Tenggara (ibukota di Muara Siberut)

\section{Pemantapan Pembentukan Provinsi Kepulauan Mentawai}

Pemerintah daerah harus bersinergi dengan pemerintah pusat, masyarakat Mentawai dan pihak-pihak yang berkepentingan dalam pembentukan Provinsi Kepulauan Mentawai. Hal ini dapat dilakukan dengan mengembangkan jumlah desa di tiap kecamatan menjadi minimal 7 desa untuk setiap kecamatannya. Selain itu, pemerintah daerah perlu mengembangkan jumlah kecamatan di tiap Kabupaten dan Kota 
menjadi minimal 7 kecamatan untuk setiap Kabupaten/Kota nya. Untuk membentuk Provinsi Kepulauan Mentawai, maka Pemerintah Daerah di 5 kabupaten dan kota yang baru dibentuk harus bersinergi dengan pemerintah pusat. Pada akhirnya akan terbentuk Provinsi Kepulauan Mentawai yang beribukota di Kota Tuapejat terdiri dari 5 Kabupaten dan Kota, yaitu Induk Kabupaten Kepulauan Mentawai, Pemekaran Kota Tuapejat, Pemekaran Kabupaten Siberut, Pemekaran Kabupaten Sipora, Pemekaran Kabupaten Pagai.

\section{Kepemimpinan Yang Transformasional dalam Perspektif Kristen}

Teori Kepemimpinan Transformasional adalah suatu teori kepemimpinan dimana pemimpin membaur dengan anggotanya, memperhatikan apa yang menjadi kebutuhan anggotanya, serta pertimbangan kemampuan kelompok dalam mengerjakan tugas. ${ }^{26}$ Hubungan yang terjalin antara pemimpin dan anggota tidak kaku, tetapi seperti saudara, serta masukan dan saran bawahan mau diterima oleh pemimpin. ${ }^{27}$ Model kepemimpinan Kristen adalah kepemimpinan yang meneladani model kepemimpinan Yesus Kristus. Yang membedakan model kepemimpinan Kristen dengan kepemimpinan dunia (yang mengandalkan kekuasaan dan kewenangan untuk menjalankan pengaruhnya) adalah model kepemimpinan ini dimulai dari kasih, kerelaan, dan keinginan untuk melayani orang lain sehingga menginspirasi dan memotivasi untuk sama-sama mencapai tujuan. ${ }^{28}$ Yesus Kristus dapat menjadi teladan yang memiliki karakter kepemimpinan transformasional dimana beliau memiliki wibawa untuk memimpin dengan perencanaan dan strategi yang matang. ${ }^{29}$

\section{Kesimpulan}

Pemekaran Provinsi Kepulauan Mentawai adalah wacana yang perlu dikembangkan dan direalisasikan melihat faktor-faktor sosial-budaya, sosial-politik, dan pertahanan keamanan, utamanya sosial-budaya yang menjadikan Mentawai unik dari provinsi induknya sebagai daerah yang mayoritas penduduknya memeluk agama Kristen. Dorongan wacana ini adalah demi pemerataan ekonomi dan pembangunan yang selama ini masih berjalan dengan lambat dan juga untuk menghindari konflik komunal akibat perbedaan identitas.

Kepemimpinan Kristen yang transformasional oleh Pemerintah Daerah Kabupaten Kepulauan Mentawai hingga Pemerintah Pusat sangat diperlukan dalam

\footnotetext{
${ }^{26}$ Wendy Sepmady Hutahaean, Teori Kepemimpinan, ed. Yayuk Umaya, 1st ed. (Malang: Ahli Media Press, 2021), https://books.google.co.id/books/about/TEORI_KEPEMIMPINAN.html?id=CYMqEAAAQBAJ.

27 Simon Simon and Alvonce Poluan, "Model Kepemimpinan Yang Ideal Dalam Penataan Organisasi Gereja," SHAMAYIM: Jurnal Teologi dan Pendidikan Kristiani 1, no. 2 (2021): 133-147.

${ }^{28}$ Agus Purwanto, "Kepemimpinan Yesus Kristus Sebagai Model Kepemimpinan Kristen," Mathetes: Jurnal Teologi dan Pendidikan Kristen 1, no. 2 (2020): 131-146.

${ }^{29}$ Natonis, "Kepemimpinan Transformatif Dalam Perspektif Pendidikan Agama Kristen."
} 
pembentukan Provinsi Kepulauan Mentawai sebagaimana Yesus Kristus yang mentransformasi umat-Nya sehingga terwujud visi-Nya di dunia. Kepemimpinan transformasional dalam perspektif Kristen ini menekankan pada perencanaan dan strategi matang. Pemimpin yang transformative ikut berbaur di tengah-tengah anggotanya dan selalu memotivasi anggotanya untuk mewujudkan visi bersama.

Terdapat lima strategi dalam mentransformasi Kabupaten Kepulauan Mentawai menjadi sebuah Provinsi Kepulauan Mentawai, yaitu (1) Perencanaan dan Sosialisasi Pemekaran Daerah, (2) Pemerataan Jumlah Desa Setiap Kecamatan, (3) Pemekaran Kecamatan dan Desa Cakupannya, (4) Pembentukan Kabupaten dan Kota Baru, dan (5) Pemantapan Pembentukan Provinsi Kepulauan Mentawai.

\section{Referensi}

BPS Kabupaten Kepulauan Mentawai. "Banyaknya Desa Dan Dusun Di Kecamatan 20172018." Last modified 2018. Accessed June 30, 2021.

https://mentawaikab.bps.go.id/indicator/101/100/1/banyaknya-desa-dan-dusundi-kecamatan.html.

_-_. "Jumlah Penduduk Menurut Agama Dan Kecamatan (Jiwa), 2019-2020." Last modified 2020. Accessed June 17, 2021.

https://mentawaikab.bps.go.id/indicator/108/560/1/jumlah-penduduk-menurutagama-dan-kecamatan.html.

BPS Provinsi Sumatera Utara. "Luas Daerah Dan Jumlah Pulau Menurut Kabupaten/Kota Di Provinsi Sumatera Utara, 2020.” Last modified 2020. Accessed June 17, 2021. https://sumut.bps.go.id/statictable/2021/04/19/2066/luas-daerah-dan-jumlahpulau-menurut-kabupaten-kota-di-provinsi-sumatera-utara-2020.html.

BPS Republik Indonesia. "Jumlah Penduduk Hasil Proyeksi Menurut Provinsi Dan Jenis Kelamin (Ribu Jiwa), 2018-2020.” Last modified 2020. Accessed June 17, 2021. https://www.bps.go.id/indicator/12/1886/1/jumlah-penduduk-hasil-proyeksimenurut-provinsi-dan-jenis-kelamin.html.

Fanani, Abdul Fatah, Mahathir Muhammad Iqbal, Wahyu Astutik, and Yuni Lestari. "Kepemimpinan Transformasional Sektor Publik." Journal of Public Sector Innovations 4, no. 2 (2020): 84-90.

Herawati, Nunik Retno. “Pemekaran Daerah Di Indonesia.” Politika: Jurnal Ilmu Politik 2, no. 1 (2011): 57-65.

Hutahaean, Wendy Sepmady. Teori Kepemimpinan. Edited by Yayuk Umaya. 1st ed. Malang: Ahli Media Press, 2021.

https://books.google.co.id/books/about/TEORI_KEPEMIMPINAN.html?id=CYMqEA AAQBAJ.

Kasir, Joni Abdul. "Pemerataan Pembangunan, Mentawai Ajukan Pemekaran 40 Desa Baru." Last modified 2019. Accessed June 17, 2021.

https://klikpositif.com/baca/48396/pemerataan-pembangunan-mentawai-ajukanpemekaran-40-desa-baru.html.

Kasman, Syaiful. “BABI : TERNAK KESAYANGAN ORANG MENTAWAI.” Jurnal 
Antropologi: Isu-Isu Sosial Budaya 17, no. 1 (2015): 87-95.

Kemenko PMK. "Pemerintah Matangkan Rencana Penataan Desa Di Kabupaten Kepulauan Mentawai." Last modified 2021. Accessed June 29, 2021. https://www.kemenkopmk.go.id/pemerintah-matangkan-rencana-penataan-desadi-kabupaten-kepulauan-mentawai.

Krissandi, Apri Damai Sagita, Sebastianus Widanarto, and Wilma Endah Utami. "Posthumanisme Masyarakat Mentawai." Prosiding Seminar Nasional Indonesia di Tengah Tantangan Pascahumanisme: Merumuskan Model Humanisme Baru (2019): 9-15.

Kusbiantoro, Krismanto, Roy Anthonius, and Iwan Santosa. "Modernisasi Dan Komersialisasi Uma Masyarakat Mentawai Sebuah Deskripsi Fenomenologis.” Jurnal Sosioteknologi 15, no. 2 (2016): 187-199.

Marta, Joan. "Faktor Pemicu Dan Penentu Kelayakan Pemekaran Wilayah Di Sumatera Barat (Pendekatan Sosial Ekonomi)." Jurnal Ecosains 1, no. 1 (2012): 67-76.

Mentawai, Kominfo. "Yudas: Sepintas Dalam Sejarah Terkait Mekarnya Mentawai Menjadi Kabupaten.” Last modified 2019. Accessed June 17, 2021.

http://www.mentawaikab.go.id/berita/detail/yudas--sepintas-dalam-sejarahterkait-mekarnya-mentawai-menjadi-kabupaten-.

Muqoyyidin, Andik Wahyun. "Pemekaran Wilayah Dan Otonomi Daerah Pasca Reformasi Di Indonesia: Konsep, Fakta Empiris, Dan Rekomendasi Ke Depan." Jurnal Konstitusi 10, no. 2 (2013): 287-309.

Natonis, Harun Y. "Kepemimpinan Transformatif Dalam Perspektif Pendidikan Agama Kristen." Voice of Wesley: Jurnal Ilmiah Musik dan Agama 3, no. 2 (2020): 15-27.

Presiden Republik Indonesia. Lampiran Peraturan Presiden Republik Indonesia No. 63 Tahun 2020 Tentang Penetapan Daerah Tertinggal Tahun 2020-2024. Jakarta, 2020.

-_- Penjelasan Atas Peraturan Pemerintah Republik Indonesia No. 78 Tahun 2007 Tentang Cara Pembentukan, Penghapusan, Dan Penggabungan Daerah. Jakarta, 2007.

Purwanto, Agus. "Kepemimpinan Yesus Kristus Sebagai Model Kepemimpinan Kristen." Mathetes: Jurnal Teologi dan Pendidikan Kristen 1, no. 2 (2020): 131-146.

Rahmat, Aulia. "Reaktualisasi Nilai Islam Dalam Budaya Minangkabau Melalui Kebijakan Desentralisasi." El-HARAKAH: Jurnal Budaya Islam 13, no. 1 (2011).

Republik Indonesia. Undang-Undang Dasar Negara Republik Indonesia. Jakarta, 2002.

-_- Undang-Undang Republik Indonesia No. 49 Tahun 1999 Tentang Pembentukan Kabupaten Kepulauan Mentawai. Jakarta, 1999.

_-_- Undang-Undang Republik Indonesia Nomor 32 Tahun 2004 Tentang Pemerintahan Daerah. Jakarta, 2004.

Saleleubaja, Rus Akbar. "Usulan Sumbar Menjadi DIM, Ini Kata Sejumlah Tokoh Dari Mentawai." Last modified 2021. Accessed June 17, 2021. 
https://www.mentawaikita.com/baca/5216/usulan-sumbar-menjadi-dim-ini-katasejumlah-tokoh-dari-mentawai.

Sekretariat Kabinet Republik Indonesia. "Usulan 314 DOB Dikaji, Mendagri: Pemerintah Tetap Berlakukan Moratorium Pemekaran Daerah.” Last modified 2019. Accessed June 29, 2021. https://setkab.go.id/usulan-314-dob-dikaji-mendagri-pemerintahtetap-berlakukan-moratorium-pemekaran-daerah.

Simon, Simon, and Alvonce Poluan. "Model Kepemimpinan Yang Ideal Dalam Penataan Organisasi Gereja." SHAMAYIM: Jurnal Teologi dan Pendidikan Kristiani 1, no. 2 (2021): 133-147.

Wiryono, Herry. “Cilegon: Dari Kota Administratif Sampai Kota (1986-2005)." Patanjala 1, no. 3 (2009): 296-306.

Zebua, Ben Hansel N., and M. Y. Tiyas Tinov. "Upaya Pemekaran Provinsi Kepulauan Nias (Studi Kepentingan Elit Politik)." Jurnal Online Mahasiswa Fakultas Ilmu Sosial dan Ilmu Politik 4, no. 1 (2017). 